Original article

\title{
A study of in-vitro interaction of Ketotifen Fumarate with Domperidone at different gastric and intestinal pH
}

\author{
Mohammad Aktar Sayeed ${ }^{1}$, Fuad Mohammed Farhad ${ }^{1}$, Syed Mohammed Tareq ${ }^{2}$, Md. Ikram ${ }^{1}$, Md. Nurul Islam ${ }^{1}$, \\ Saiful Alam Siddique ${ }^{1}$, Dipesh Das ${ }^{3}$ \\ ${ }^{1}$ International Islamic University Chittagong, Bangladesh \\ ${ }^{2}$ Southern University Bangladesh \\ ${ }^{3}$ University of Chittagong, Bangladesh
}

Received 9 December 2013, Revised 15 April 2014, Accepted 10 June 2014

(C) 2013, Sayeed M.S., Farhad F.M., Tareq S.M., Ikram M., Islam M.N., Siddique S.A., Das D.

(C) 2014, Russian Open Medical Journal

\begin{abstract}
Aim - The main focus of the project was to identify whether there is any interaction between Ketotifen Fumarate (antihistamine) and domperidone (Antiemetic/dopaminergic antagonist) present or not at simulated gastric and intestinal solutions of different $\mathrm{pH}$. Methods - Using Job's continuous-variation analysis the possible drug-drug interaction was determined at a fixed temperature $(37 \mathrm{O} C)$ at the studied $\mathrm{pH}$. From Job's continuous-variation analysis the views of drug-drug interaction at different concentration ratio at all $\mathrm{pH}(0.4,1.2,2.0,2.8,6.8$, and 7.4$)$ except 6.0 were noted. Results - Data obtained from spectroscopic analysis showed decrease in free-drug concentration of both of the drugs analyzed when they were within the same gastric simulated solution. Conclusion - Concurrent administration of Ketotifen Fumarate and domperidone would result in the formation of a stable complex and this is likely to reduce the the rapeutic activities of both drugs.
\end{abstract}

Keywords: drug interaction, Domperidone, job's plot, Ketotifen fumarate, pH, spectral pattern

Cite as Sayeed MS, Farhad FM, Tareq SM, Ikram M, Islam MN, Siddique SA, Das D. A study of in-vitro interaction of Ketotifen Fumarate with Domperidone at different gastric and intestinal pH. Russian Open Medical Journal 2014; 3: 0204.

Correspondence to Fuad Mohammed Farhad. Address: Department of Pharmacy, International Islamic University Chittagong, Bangladesh.

Tel: +88 01920555598. E-mail: fuadekushe_52@yahoo.com

\section{Introduction}

The drug ketotifen is a benzocycloheptathiophene derivative which has been reported to have anti- histaminic and antianaphylactic properties [1]. Ketotifen antagonizes histamine at $\mathrm{H} 1$ receptors at mast cells, inhibits calcium uptake, blocks passive cutaneous anaphylactic reaction, reverses isoprenaline induced beta-adrenoceptor tachyphylaxis, and inhibits both allergeninduced and drug-induced asthma [2]. Through a number of clinical trials, this drug has been shown to have a beneficial effect in the treatment of asthma [3-4]. Domperidone is an antidopaminergic drug used to suppress nausea and vomiting, as a prokinetic agent and for promoting lactation. It is a specific blocker of dopamine receptors. It speeds gastrointestinal peristalsis, causes prolactin release, and is used as antiemetic and tool in the study of dopaminergic mechanisms. There is some evidence that domperidone has antiemetic activity [5]. Domperidone is used, along with metoclopramide, cyclizine, and 5HT3 receptor antagonists to treat nausea and vomiting. Domperidone can be used in patients with Parkinson's disease [6] because, unlike metoclopramide [7], domperidone does not cross the blood-brain barrier. Domperidone has also been found effective in the treatment of gastroparesis [8], and for paediatric gastroesophageal reflux. The major goal of the present study was to find out whether two drugs-ketotifen and domperidone might undergo drug-drug interaction at simulated gastric fluid having various $\mathrm{pH}$. The absorbance of drugs at those solutions was taken and analyzed using Job's plot [9].

\section{Material and methods}

\section{Materials}

All the chemicals and reagents used in this study were of analytical grade and were stored under optimum storage conditions. The experimental mixtures and solutions were prepared in standard volumetric flasks about one hour prior to recording the data.

Drugs used in the study: Ketotifen fumarate and Domperidone.

The $\lambda$ max value of drug used in the study: $300 \mathrm{~nm}$ (The $\lambda$ max Ketotifen fumarate).

Instrument used: $\mathrm{pH}$ Meter, UV/VIS Spectrophotometer, Electronic balance, Water bath

Solvents: i) Distilled water, ii) Hydrochloric acid, iii) Ethanol.

\section{Preparation of Hydrochloric acid}

In order to prepare Hydrochloride acid of $0.1 \mathrm{M}$ concentration, $9.1 \mathrm{ml}$ of hydrochloric acid (Molecular weight $36.5 \mathrm{gm} / \mathrm{mol}, 37 \%$ concentrated) was taken in a liter volumetric flask and the volume made up with distilled water to the mark. Similarly $18.18 \mathrm{ml}$ of $\mathrm{HCl}$ 
acid was diluted in a liter volumetric flask up to the mark with distilled water to make the solution of $0.2 \mathrm{M}$ concentration.

\section{Preparation of Potassium chloride}

In order to prepare Potassium chloride of $0.2 \mathrm{M}$ concentration, Potassium chloride (14.9 gm), (Molecular weight $74.55 \mathrm{gm} / \mathrm{mol}$ ) was dissolved in distilled water in a liter flask and the volume made up to the mark with same solvent.

\section{Preparation of potassium dihydrogen phosphate}

In order to prepare potassium dihydrogen phosphate of $0.1 \mathrm{M}$ concentration, Potassium chloride (13.609 gm), (Molecular weight $136.09 \mathrm{gm} / \mathrm{mol}$ ) was dissolved in distilled water in a liter flask and the volume made up to the mark with same solvent.

\section{Preparation of Sodium hydroxide}

In order to prepare of $0.1 \mathrm{M}$ concentration, sodium hydroxide pellets ( $20 \mathrm{gms}$ ), (Molecular weight $40 \mathrm{gm} / \mathrm{mol}$ ) were taken in a 500 $\mathrm{ml}$ volumetric flask, dissolved in little distilled water and volume was made up to the mark with the same solvent. $100 \mathrm{ml}$ of this solution (1 $\mathrm{M}$ concentration) was further diluted in $500 \mathrm{ml}$ volumetric flask with distilled water, resulting concentration was $0.2 \mathrm{M}$.

\section{Preparation of acidic buffer ( $\mathrm{pH} 0.4,1.2,2.0$, and 2.8)}

These buffers are prepared by using sodium chloride, potassium chloride, sodium hydroxide and hydrochloric acid with the help of $\mathrm{pH}$ meter.

\section{Preparation of Basic buffer (pH 6.0, 6.8, and 7.4)}

These buffers are prepared by using Potassium dihydrogen phosphate $\left(\mathrm{KH}_{2} \mathrm{PO}_{4}\right)$, potassium chloride, sodium hydroxide and hydrochloric acid with the help of $\mathrm{pH}$ meter.

\section{Preparation of Ketotifen Fumarate solution}

$100 \mathrm{ml}$ of $1 * 10^{-3} \mathrm{M}$ solution of Ketotifen Fumarate was prepared as the stock solution by dissolving $0.425 \mathrm{gm}$ of Ketotifen Fumarate in $100 \mathrm{ml}$ of distilled water in a $100 \mathrm{ml}$ Volumetric flask. To prepare $1 * 10^{-5} \mathrm{M}$ solution of Ketotifen Fumarate, $1 \mathrm{ml}$ of $1 * 10^{-3} \mathrm{M}$ solution was taken in another $100 \mathrm{ml}$ volumetric flask and the volume was adjusted by distilled water up to the mark.

\section{Preparation of Domperidone solution}

$100 \mathrm{ml}$ of $1 * 10^{-4} \mathrm{M}$ solution of Domperidone was prepared as the stock solution by dissolving $0.425 \mathrm{gm}$ of Domperidone in $100 \mathrm{ml}$ of distilled water in a $100 \mathrm{ml}$ Volumetric flask. To prepare $1 * 10^{-5} \mathrm{M}$ solution of Domperidone, $1 \mathrm{ml}$ of $1 * 10^{-4} \mathrm{M}$ solution was taken in another $10 \mathrm{ml}$ volumetric flask and the volume was adjusted by distilled water up to the mark.

\section{Methods}

Job plot, also known as the method of continuous variation or Job's method was used to analyze the free drug concentration after concurrent administration using the observed spectroscopic data. According to Job's method (Job, 1971) a series of solutions were prepared in which the analytical concentration of one reactant (usually the cation) was held constant while that of the other was varied. The absorbance of a series of Ketotifen
Fumarate with domperidone in different molar ratios $(1: 9,2: 8,3: 7$, $4: 6,5: 5,6: 4,7: 3,8: 2,9: 1)$ was measured by keeping the total molar concentration constant. The observed absorbance of the mixtures at various molar fractions was subtracted from the sum of the values for the free drugs (Ketotifen Fumarate and domperidone). The absorbance difference (D) was then plotted against the molar fractions of the drug in the mixtures. If the formation constant is reasonably favourable, two straight lines with different slopes that intersect at a molar ratio that corresponds to the ratio of drugs in the complex are obtained.

\section{Results}

In the present investigation, the interaction of Ketotifen Fumarate and Domperidone has been studied by different methods of analysis under different $\mathrm{pH}(0.4,1.2,2.0,2.8,6.0,6.8$ and 7.4) at different concentrations. The spectral characteristics and spectrophotometric analysis of the complexation process have been evaluated. The results obtained from various methods are discussed below.

\section{Spectral studies of interaction of Ketotifen Fumarate \& Domperidone}

In spectral observation analysis, each of the drugs studied showed absorption in UV-VIS region. The molecular species of Ketotifen Fumarate \& Domperidone when separately mixed showed some changes in absorption characteristics of this drug molecule including some shifts in the absorption maxima. Initial detection of complexation of Ketotifen Fumarate with Domperidone was done from the nature of spectra of pure compounds as well as their 1:1, 1:2 and 2:1 mixtures in buffer solution of $\mathrm{pH} 0.4,1.2,2.0,2.8,6.0,6.8$ and 7.4 at a fixed concentration $\left(1 * 10^{-5} \mathrm{M}\right)$. It is obvious that each compound has its unique molecular structure or electronic configuration which is responsible for absorption of light in the form of ultraviolet or visible form. For this reason the spectrum of any pure compound obtained from UV-spectrum will be of one kind that will be totally different from the other compound or the complex of that compound with other compounds. It is because interaction between two compounds may lead to form complex which has different light absorption capacity (due to change in physicochemical and optical properties) and the spectral pattern is altered. Thus alteration in spectral pattern may be regarded as an indicator for the primary interaction of drugs. The spectra of target molecules alone and mixture of Ketotifen Fumarate with Domperidone showed significant changes in their absorption intensities. This may be due to the interaction of Ketotifen Fumarate with Domperidone that alter the absorption intensities as complexation occurs.

Effect of Domperidone on Ketotifen Fumarate by Job's method of continuous variation at different $\mathrm{pH}$

The molar ratios of the complexes of Ketotifen Fumarate with Domperidone were estimated by Job's spectrophotometric method of continuous variation. The observed absorbance values measured in $\mathrm{pH} 0.4,1.2,2.0,2.8,6.0,6.8$ and 7.4 at various concentrations $1 * 10^{-5} \mathrm{M}$ to $9 * 10^{-5} \mathrm{M}$ Ketotifen Fumarate with Domperidone at $300 \mathrm{~nm}$ is given in Tables 1-7. In this method, solutions of different concentrations of Ketotifen fumarate and Domperidone were prepared by plotting corrected absorbance against the volume fraction of one reactant. It may be mentioned that drug solutions with identical analytical concentrations are 
mixed in such a way that total volume and the total moles of reactant in each mixture is constant but the mole ratio of the reactants varies systematically. At pH 0.4, 1.2, 2.0, 2.8, 6.0, 6.8 and 7.4 Ketotifen Fumarate forms strong 1:1 complex with Domperidone.

Table 1. Values of job's plot for complexation of Ketotifen Fumarate with Domperidone at $\mathrm{pH} 0.4$

\begin{tabular}{|c|c|c|c|c|c|}
\hline 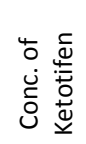 & 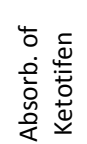 & 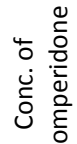 & 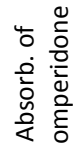 & 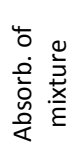 & 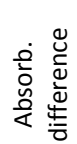 \\
\hline
\end{tabular}

\begin{tabular}{cccccc}
\hline $\mathrm{M} \times 10^{-5}$ & $\mathrm{~A}$ & $\mathrm{M} \times 10^{-5}$ & $\mathrm{~B}$ & $\mathrm{C}$ & $\mathrm{D}=(\mathrm{A}+\mathrm{B})-\mathrm{C}$ \\
\hline 1 & 0.160 & 9 & 1.028 & 0.297 & 0.891 \\
2 & 0.268 & 8 & 0.918 & 0.302 & 0.884 \\
3 & 0.419 & 7 & 0.8 & 0.317 & 0.902 \\
4 & 0.543 & 6 & 0.689 & 0.347 & 0.885 \\
5 & 0.687 & 5 & 0.575 & 0.424 & 0.838 \\
6 & 0.826 & 4 & 0.441 & 0.538 & 0.729 \\
7 & 0.971 & 3 & 0.334 & 0.679 & 0.626 \\
8 & 1.129 & 2 & 0.193 & 0.910 & 0.466 \\
9 & 1.229 & 1 & 0.116 & 1.015 & 0.330 \\
\hline
\end{tabular}

Table 2. Values of job's plot for complexation of Ketotifen Fumarate with Domperidone at $\mathrm{pH} 1.2$

\begin{tabular}{|c|c|c|c|c|c|}
\hline 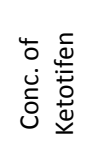 & 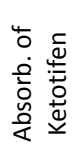 & 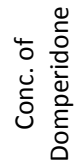 & 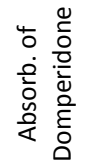 & 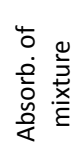 & 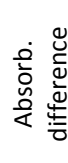 \\
\hline
\end{tabular}

\begin{tabular}{cccccc}
\hline $\mathrm{M} \times 10^{-5}$ & $\mathrm{~A}$ & $\mathrm{M} \times 10^{-5}$ & $\mathrm{~B}$ & $\mathrm{C}$ & $\mathrm{D}=(\mathrm{A}+\mathrm{B})-\mathrm{C}$ \\
\hline 1 & 0.14 & 9 & 0.927 & 0.230 & 0.837 \\
2 & 0.300 & 8 & 0.817 & 0.239 & 0.878 \\
3 & 0.403 & 7 & 0.711 & 0.258 & 0.856 \\
4 & 0.556 & 6 & 0.603 & 0.308 & 0.851 \\
5 & 0.670 & 5 & 0.501 & 0.395 & 0.776 \\
6 & 0.820 & 4 & 0.386 & 0.524 & 0.682 \\
7 & 0.970 & 3 & 0.277 & 0.679 & 0.568 \\
8 & 1.093 & 2 & 0.192 & 0.860 & 0.376 \\
9 & 1.234 & 1 & 0.143 & 1.256 & 0.121 \\
\hline
\end{tabular}

Table 3. Values of job's plot for complexation of Ketotifen Fumarate with Domperidone at pH 2.0

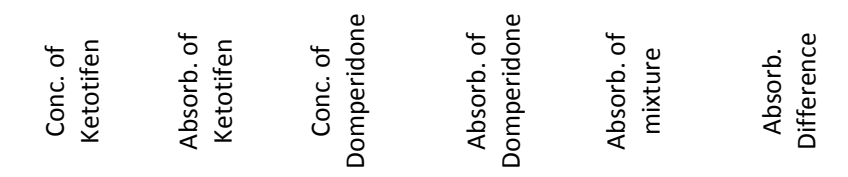

\begin{tabular}{cccccc}
\hline $\mathrm{M} \times 10^{-5}$ & $\mathrm{~A}$ & $\mathrm{M} \times 10^{-5}$ & $\mathrm{~B}$ & $\mathrm{C}$ & $\mathrm{D}=(\mathrm{A}+\mathrm{B})-\mathrm{C}$ \\
\hline 1 & 0.167 & 9 & 1.071 & 0.270 & 0.968 \\
2 & 0.318 & 8 & 0.935 & 0.280 & 0.973 \\
3 & 0.446 & 7 & 0.813 & 0.307 & 0.952 \\
4 & 0.608 & 6 & 0.696 & 0.353 & 0.951 \\
5 & 0.773 & 5 & 0.56 & 0.463 & 0.870 \\
6 & 0.915 & 4 & 0.464 & 0.588 & 0.791 \\
7 & 1.059 & 3 & 0.324 & 0.742 & 0.641 \\
8 & 1.118 & 2 & 0.221 & 0.967 & 0.362 \\
9 & 1.349 & 1 & 0.112 & 1.261 & 0.200 \\
\hline
\end{tabular}

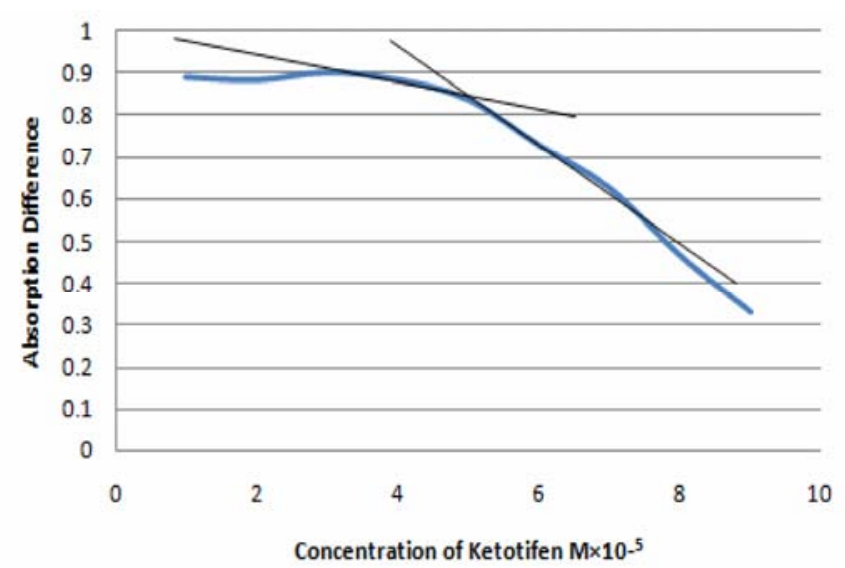

Figure 1. Job's plot for complexation of Ketotifen Fumarate with Domperidone at $\mathrm{pH} 0.4$

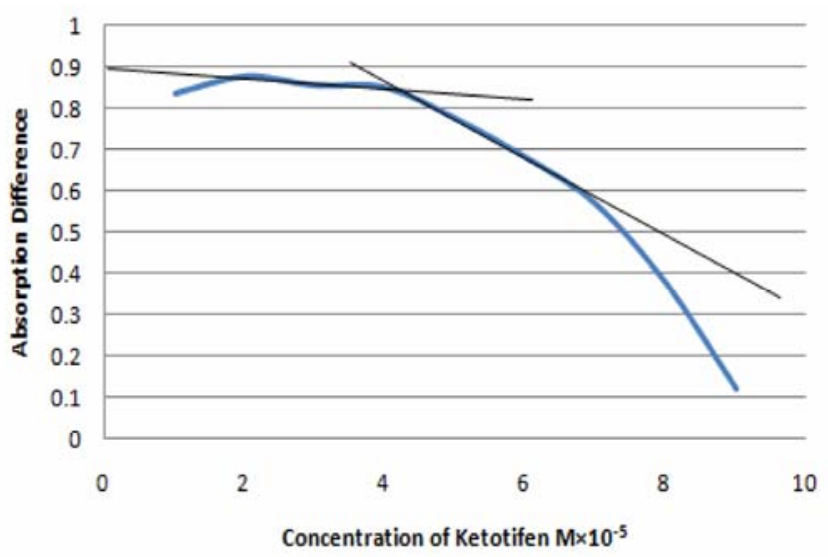

Figure 2. Job's plot for complexation of Ketotifen Fumarate with Domperidone at pH 1.2

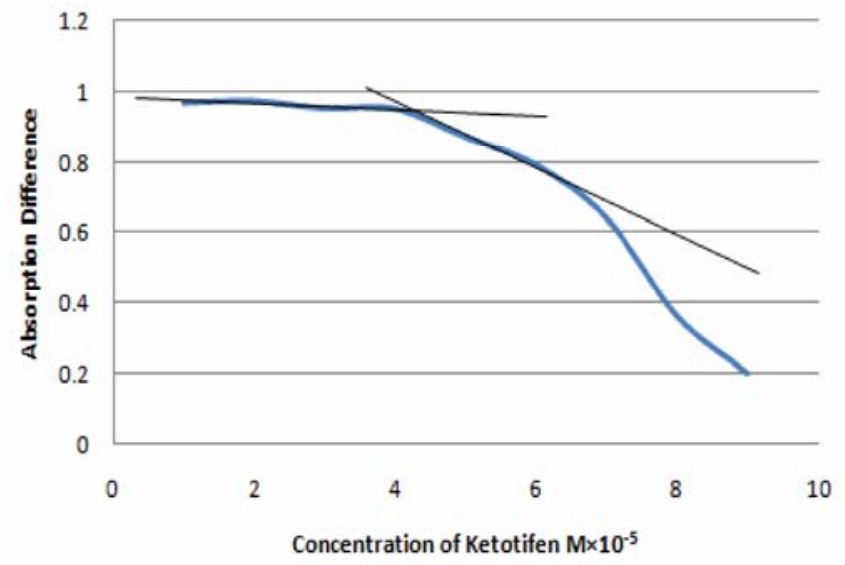

Figure 3. Job's plot for complexation of Ketotifen Fumarate with Domperidone at $\mathrm{pH} \mathbf{2 . 0}$ 
Table 4. Values of job's plot for complexation of Ketotifen Fumarate with Domperidone at pH 2.8

\begin{tabular}{|c|c|c|c|c|c|}
\hline 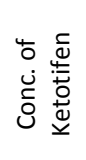 & 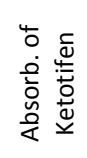 & 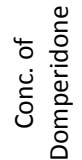 & 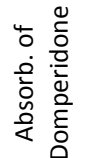 & 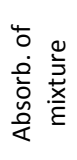 & 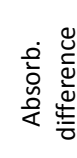 \\
\hline
\end{tabular}

\begin{tabular}{cccccc}
\hline $\mathrm{M} \times 10^{-5}$ & $\mathrm{~A}$ & $\mathrm{M} \times 10^{-5}$ & $\mathrm{~B}$ & $\mathrm{C}$ & $\mathrm{D}=(\mathrm{A}+\mathrm{B})-\mathrm{C}$ \\
\hline 1 & 0.137 & 9 & 1.019 & 0.264 & 0.892 \\
2 & 0.275 & 8 & 0.901 & 0.268 & 0.908 \\
3 & 0.426 & 7 & 0.768 & 0.286 & 0.908 \\
4 & 0.588 & 6 & 0.651 & 0.321 & 0.918 \\
5 & 0.722 & 5 & 0.54 & 0.408 & 0.854 \\
6 & 0.868 & 4 & 0.433 & 0.557 & 0.744 \\
7 & 0.993 & 3 & 0.303 & 0.696 & 0.600 \\
8 & 1.126 & 2 & 0.193 & 0.923 & 0.396 \\
9 & 1.271 & 1 & 0.103 & 1.104 & 0.270 \\
\hline
\end{tabular}

Table 5. Values of job's plot for complexation of Ketotifen Fumarate with Domperidone at pH 6.0

\begin{tabular}{|c|c|c|c|c|c|}
\hline 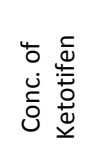 & 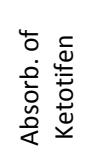 & 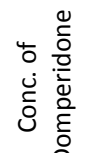 & 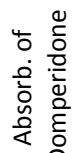 & 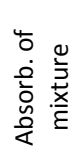 & 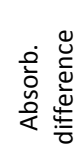 \\
\hline
\end{tabular}

\begin{tabular}{cccccc}
\hline $\mathrm{M} \times 10^{-5}$ & $\mathrm{~A}$ & $\mathrm{M} \times 10^{-5}$ & $\mathrm{~B}$ & $\mathrm{C}$ & $\mathrm{D}=(\mathrm{A}+\mathrm{B})-\mathrm{C}$ \\
\hline 1 & 0.161 & 9 & 0.350 & 0.100 & 0.411 \\
2 & 0.340 & 8 & 0.317 & 0.132 & 0.525 \\
3 & 0.471 & 7 & 0.285 & 0.201 & 0.555 \\
4 & 0.623 & 6 & 0.225 & 0.260 & 0.588 \\
5 & 0.702 & 5 & 0.220 & 0.372 & 0.55 \\
6 & 0.880 & 4 & 0.172 & 0.532 & 0.52 \\
7 & 0.973 & 3 & 0.111 & 0.620 & 0.464 \\
8 & 1.271 & 2 & 0.082 & 0.921 & 0.432 \\
9 & 1.190 & 1 & 0.040 & 1.031 & 0.199 \\
\hline
\end{tabular}

Table 6. Values of job's plot for complexation of Ketotifen Fumarate with Domperidone at $\mathrm{pH} 6.8$

\begin{tabular}{|c|c|c|c|c|}
\hline 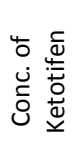 & 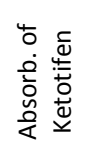 & 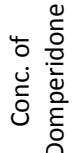 & 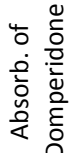 & 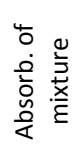 \\
\hline
\end{tabular}

\begin{tabular}{cccccc}
\hline $\mathrm{M} \times 10^{-5}$ & $\mathrm{~A}$ & $\mathrm{M} \times 10^{-5}$ & $\mathrm{~B}$ & $\mathrm{C}$ & $\mathrm{D}=(\mathrm{A}+\mathrm{B})-\mathrm{C}$ \\
\hline 1 & 0.123 & 9 & 0.947 & 0.206 & 0.864 \\
2 & 0.259 & 8 & 0.841 & 0.234 & 0.866 \\
3 & 0.420 & 7 & 0.657 & 0.242 & 0.835 \\
4 & 0.528 & 6 & 0.550 & 0.292 & 0.786 \\
5 & 0.676 & 5 & 0.452 & 0.388 & 0.74 \\
6 & 0.811 & 4 & 0.362 & 0.513 & 0.66 \\
7 & 0.931 & 3 & 0.274 & 0.660 & 0.545 \\
8 & 1.076 & 2 & 0.175 & 0.858 & 0.393 \\
9 & 1.174 & 1 & 0.102 & 1.020 & 0.256 \\
\hline
\end{tabular}

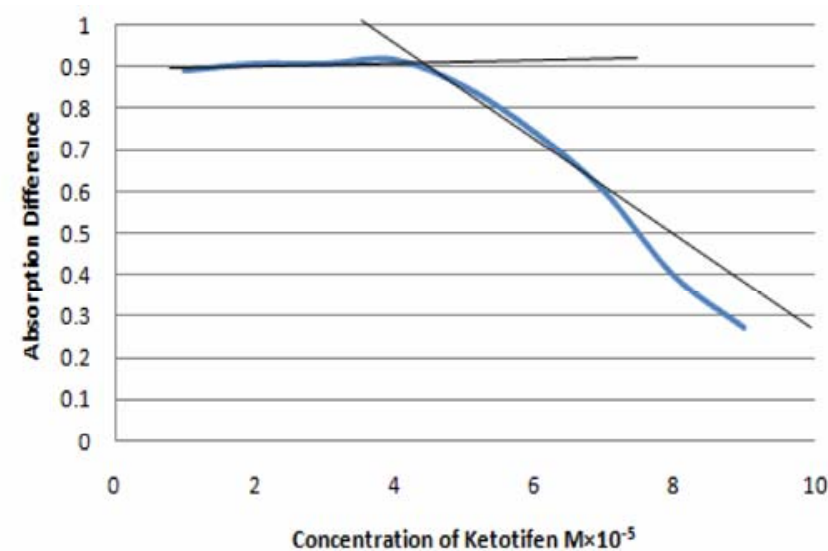

Figure 4. Job's plot for complexation of Ketotifen Fumarate with Domperidone at $\mathrm{pH} 2.8$

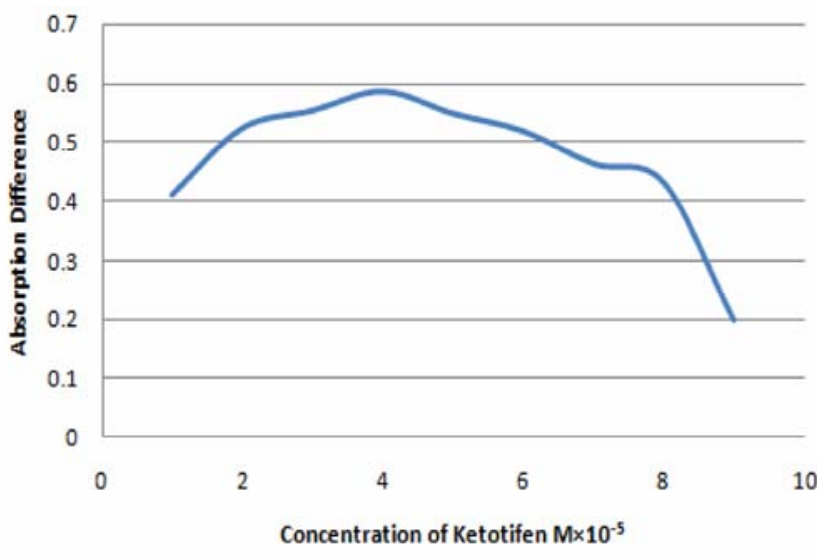

Figure 5. Job's plot for complexation of Ketotifen Fumarate with Domperidone at $\mathrm{pH} 6.0$

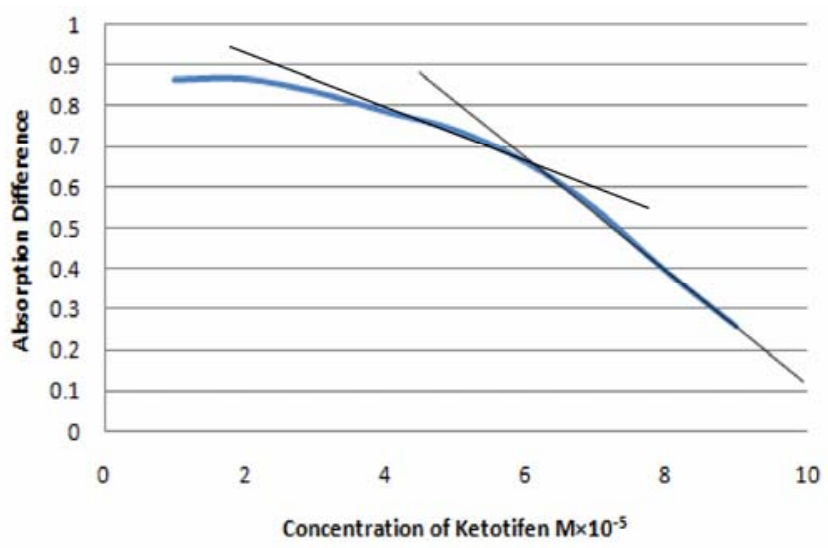

Figure 6. Job's plot for complexation of Ketotifen Fumarate with Domperidone at $\mathrm{pH} 6.8$ 
Table 7. Values of job's plot for complexation of complexation of Ketotifen Fumarate with Domperidone at pH 7.4

\begin{tabular}{|c|c|c|c|c|c|}
\hline 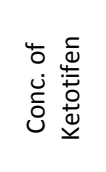 & 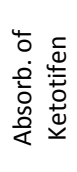 & 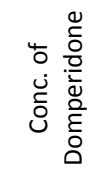 & 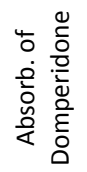 & 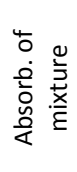 & 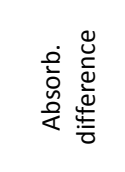 \\
\hline $\mathrm{M} \times 10^{-5}$ & A & $\mathrm{M} \times 10^{-5}$ & B & C & $D=(A+B)-C$ \\
\hline 1 & 0.125 & 9 & 0.678 & 0.026 & 0.777 \\
\hline 2 & 0.254 & 8 & 0.566 & 0.052 & 0.787 \\
\hline 3 & 0.380 & 7 & 0.527 & 0.099 & 0.808 \\
\hline 4 & 0.527 & 6 & 0.431 & 0.208 & 0.750 \\
\hline 5 & 0.661 & 5 & 0.366 & 0.331 & 0.696 \\
\hline 6 & 0.782 & 4 & 0.286 & 0.474 & 0.594 \\
\hline 7 & 0.902 & 3 & 0.225 & 0.625 & 0.502 \\
\hline 8 & 1.031 & 2 & 0.138 & 0.826 & 0.343 \\
\hline 9 & 1.132 & 1 & 0.084 & 0.998 & 0.218 \\
\hline
\end{tabular}

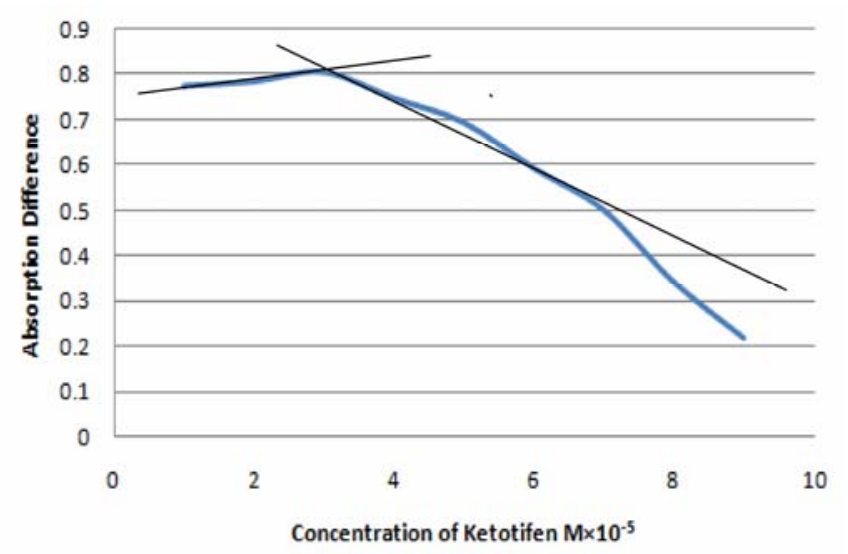

Figure 7. Job's plot for complexation of Ketotifen Fumarate with Domperidone at $\mathrm{pH} 7.4$

\section{Discussion}

Previous works on human subjects as well as animal models suggest that Domperidone goes into a number of drug-drug interactions [10-12]. As Ketotifen Fumerarate and Domperidone are often prescribed together, this study investigates the possible interaction between these two drugs through in vitro study. The two drugs under investigation were interacted together at different $\mathrm{pH}$. Different concentrations comprising $1 * 10^{-5} \mathrm{M}$ to $9 * 10^{-5} \mathrm{M}$ of ketotifen were interacted with domperidone. The breakdowns in the curves of ketotifen were found at $5^{*} 10^{-5}, 4 * 10^{-5}$, $4 * 10^{-5}, 4 * 10^{-5}, 6 * 10^{-5}$ and $3 * 10^{-5}$ at the $\mathrm{pH}$ of $0.4,1.2,2.0,2.8,6.8$ and 7.4 respectively. However, no break in the curve at $\mathrm{pH} 6$ was observed. So it was assumed that there was no interaction at $\mathrm{pH} 6$.

\section{Conclusion}

The experimental results indicate that interaction of ketotifen with domperidone decreases the free drug concentration of both drugs which may result in decreased affinity towards the receptors. Consequently one or both drugs may show diminished pharmacological activity in the system. However, further study using animal model is required to estimate the bioavailability of these drugs when administered into the system.

\section{Acknowledgement}

This study would not have been possible unless we couldn't get help from Department of Pharmacy, International Islamic University Chittagong. This department provided us with all equipments and materials to complete this task. We are obliged to our friend Jannatul Ferdous Mithu who supported and encouraged us throughout the process.

\section{Conflict of interest}

No conflict of interest has been declared by the authors.

\section{References}

1. Martin U, Romer E. Ketotifen, a histamine release inhibitor. Monogr Allergy 1977; 12: 145-149. (PMID: 72350)

2. Craps L, Greenwood C, Radielovic P. Clinical investigation of agents with prophylactic anti-allergic effects in bronchial asthma. Clinical Allergy 1978; 8: 373-382. (PMID: 101313)

3. Hoshino M, Nakamura $\mathrm{Y}$, Sim JJ, Tomioka H. A comparative study of the effects of ketotifen, disodium cromoglycate, and beclomethasone dipropionate on bronchial mucosa and asthma symptoms in patients with atopic asthma. Respiratory Medicine 1998; 92: 942-950. (PMID: 10070568) (doi: 10.1016/S0954-6111(98)90194-9)

4. Tinkelman DG, Moss BA, Bukantz SC, Sheffer AL, Dobken JH, Chodosh $S$, et al. A multicenter trial of the prophylactic effect of ketotifen, chlorpheniramine, and placebo in atopic asthma. I Allergy Clin Immunol 1985; 76(3): 487-497.

5. Swann IL, Thompson EN, Qureshi K. Domperidone or metoclopramide in preventing chemotherapeutically induced nausea and vomiting. British Medical Journal 1979; 2(6199): 1188. (PMID: 519355) (doi: 10.1136/bmj.2.6199.1188)

6. Shindler JS, Finnerty GT, Towlson K, Dolan AL, Davies CL, Parkes JD. Domperidone and levodopa in Parkinson's disease. British Journal of Clinical Pharmacology 1984; 18(6): 959-962. (PMID: 6529536)

7. Australian Medicines Handbook 2006. S. Rossi Eds. Adelaide: Australian Medicines Handbook, 2006.

8. Silvers D, Kipnes M, Broadstone V, Patterson D, Quigley EM, McCallum $\mathrm{R}$, et al. Domperidone in the management of symptoms of diabetic gastroparesis: efficacy, tolerability, and quality-of-life outcomes in a multicenter controlled trial. DOM-USA-5 Study Group. Clin Ther1998; 20(3): 438-453. (doi: 10.1016/S0149-2918(98)80054-4) (PMID: 9663360)

9. Job P. Job's method of continuous variation. Ann Chim 1928; 9: 113203.

10. Yoshizato T, Kotegawa T, Imai H, Tsutsumi K, Imanaga J, Ohyama T, Ohashi K. Itraconazole and domperidone: a placebo-controlled drug interaction study. Eur J Clin Pharmacol 2012; 68(9): 1287-1294. (doi: 10.1007/s00228-012-1258-x) (PMID: 22418831)

11. Boyce MJ, Baisley KJ, Warrington SJ. Pharmacokinetic interaction between domperidone and ketoconazole leads to QT prolongation in healthy volunteers: a randomized, placebo-controlled, double-blind, crossover study. Br J Clin Pharmacol 2012; 73(3): 411-421. (doi: 10.1111/j.1365-2125.2011.04093.x)

12. Bawazir SA, Al-Hassan MI, Matar KM, Tekle A. The effect of domperidone on theophylline disposition in the rat. Biopharm Drug Dispos 1989; 10(6): 531-535. (PMID: 2611354)

\section{Authors:}

Mohammad Aktar Sayeed - Associate professor, Department of Pharmacy, International Islamic University Chittagong, Bangladesh;

Fuad Mohammed Farhad - B.Pharm, International Islamic University Chittagong, Bangladesh;

Syed Mohammed Tareq - Assistant professor, Department of Pharmacy, Faculty of Science and Engineering, Southern University Bangladesh;

Md. Ikram - B.Pharm, International Islamic University Chittagong, Bangladesh; 
Md. Nurul Islam - B.Pharm, International Islamic University Chittagong, Bangladesh;

Saiful Alam Siddique - B.Pharm, International Islamic University Chittagong, Bangladesh;

Dipesh Das - Bachelor of Science in Genetics, University of Chittagong, Bangladesh. 